\title{
The importance of molecular diagnosis in severe sepsis determined by Neisseria meningitidis in the intensive care unit
}

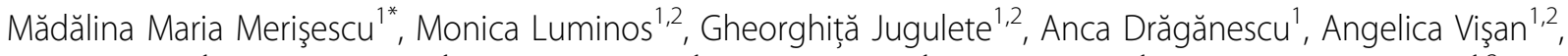 \\ Anuța Bilaşco ${ }^{1}$, Camelia Kouris ${ }^{1}$, Sabina Șchiopu', Dragoş Florea ${ }^{1}$, Endis Osmann', Adrian Streinu-Cercel ${ }^{1,2}$ \\ From The 9th Edition of the Scientific Days of the National Institute for Infectious Diseases Prof Dr Matei Bals \\ Bucharest, Romania. 23-25 October 2013
}

\section{Background}

Infections caused by Neisseria meningitidis are an important cause of infant mortality worldwide. They take many clinical forms from simple respiratory infections to purpura fulminans, a severe form of sepsis, fatal in many cases. PLEX-ID is a novel method for etiologic diagnosis of bacterial infections. It can detect bacterial DNA found in various pathological products.

We studied the correlation of data obtained by classical culture methods versus molecular method results and the clinical and biological evolution of the patients under treatment.

\section{Methods}

We conducted a 24 months study from January 2011 to December 2012 on children admitted in the Intensive Care Unit of the National Institute for Infectious Diseases "Prof. Dr. Matei Balş" for severe forms of meningococcal sepsis. Positive diagnosis of sepsis was established with classical methods, clinical and laboratory criteria (hemocultures, cerebrospinal fluid cultures), as well as PLEX-ID detection. The patients were divided into two groups based on the above mentioned criteria.

\section{Results}

In the 24 months of study, 17 children were admitted to our clinic for meningococcal sepsis. In the first study group, we included 8 patients with severe meningococcal diseases. The diagnosis was established in these cases with classical methods. The mortality was $37.5 \%$ ( 3 of 8 cases).

\footnotetext{
* Correspondence: madalinamerisescu@gmail.com

${ }^{1}$ National Institute for Infectious Diseases "Prof. Dr. Matei Balş", Bucharest, Romania

Full list of author information is available at the end of the article
}

The second study group contained 9 patients diagnosed by molecular and conventional methods. In this group, 8 patients had favorable clinical evolution (88.8\%).

\section{Conclusion}

Neisseria meningitidis was found in the first 6 hours from admission and this lead to a decrease in mortality from $37.5 \%$ to $11.2 \%$. The major advantage of this new method is the possibility to establish the etiological diagnosis in the early hours of patient admission.

\section{Authors' details \\ "National Institute for Infectious Diseases "Prof. Dr. Matei Balş", Bucharest, Romania. ${ }^{2}$ Carol Davila University of Medicine and Pharmacy, Bucharest,} Romania.

Published: 16 December 2013

doi:10.1186/1471-2334-13-S1-P38

Cite this article as: Merişescu et al:: The importance of molecular diagnosis in severe sepsis determined by Neisseria meningitidis in the intensive care unit. BMC Infectious Diseases 2013 13(Suppl 1):P38.

Submit your next manuscript to BioMed Central and take full advantage of:

- Convenient online submission

- Thorough peer review

- No space constraints or color figure charges

- Immediate publication on acceptance

- Inclusion in PubMed, CAS, Scopus and Google Scholar

- Research which is freely available for redistribution

\section{Biomed Central}

() 2013 Merişescu et al; licensee BioMed Central Ltd. This is an Open Access article distributed under the terms of the Creative Commons Attribution License (http://creativecommons.org/licenses/by/2.0), which permits unrestricted use, distribution, and reproduction in any medium, provided the original work is properly cited. 